\title{
SISTEM PAKAR DIAGNOSIS PENYAKIT PADA KAMBING DENGAN METODE FORWARD CHAINING DAN CERTAINTY FACTOR
}

\author{
(Expert System for Diagnosing Goats Disease using Forward Chaining and Certainty \\ Factor)
}

\author{
Novita Nurul Fakhriyah", Fitri Bimantoro, I Gede Pasek Suta Wijaya \\ Program Studi Teknik Informatika, Fakultas Teknik, Universitas Mataram \\ JI. Majapahit 62, Mataram, Lombok NTB, INDONESIA \\ Email: novita04nurulf@gmail.com, [bimo,gpsutawijaya]@unram.ac.id
}

\begin{abstract}
Penyakit pada hewan kambing terdiri dari dua jenis yaitu penyakit menular dan tidak menular. Penyakit pada hewan perlu dilakukan penanganan yang tepat terutama penyakit menular agar tidak dapat menular pada ternak lain. Penelitian ini bertujuan untuk membangun sistem pakar yang berbasis Android untuk mendiagnosis 14 jenis penyakit pada kambing berdasarkan pengetahuan 3 orang pakar hewan dengan menggunakan metode Forward Chaining sebagai metode inferensi dan Certainty Factor sebagai metode perhitungan untuk mendapatkan nilai densitas atau tingkat kepercayaan dari hasil diagnosis penyakit pada kambing. Penelitian ini menggunakan empat jenis pengujian yaitu berupa pengujian blackbox, pengujian kuisioner (MOS), pengujian teoritis dan pengujian akurasi sistem. Dari pengujian akurasi sistem yang dilakukan, didapatkan nilai akurasi berdasarkan bobot rata-rata 3 orang pakar sebesar $85.55 \%$, sedangkan pengujian akurasi menggunakan bobot masing-masing pakar diperoleh hasil $86.66 \%$ untuk pakar $1,83.33 \%$ untuk pakar 2, dan $86.66 \%$ untuk pakar 3. Untuk pengujian MOS (Mean Opinion Score) didapatkan hasil sebesar 4.35 dari skala 5 , serta pengujian perhitungan teoritis yang mendapatkan hasil perhitungan sama antara hasil perhitungan diagnosis sistem dan diagnosis pakar. Berdasarkan hasil perngujian maka sistem pakar diagnosis penyakit pada kambing ini layak digunakan dan dikategorikan ke dalam sistem yang baik.
\end{abstract}

Keywords: Expert System, Goats Disease, Forward Chaining, Certainty Factor, Android

*Penulis Korespondensi

\section{Pendahuluan}

Kambing merupakan salah satu dari berbagai jenis hewan yang banyak dipelihara untuk kemudian diperjualbelikan karena banyak yang dapat dimanfaatkan dari kambing, misalnya dagingnya yang mengandung banyak protein, kulitnya yang dimanfaatkan sebagai kerajinan tangan dan sebagainya[1]. Menurut Badan Pusat Statistik pada tahun 2018 jumlah populasi kambing di Indonesia yaitu sebanyak 18.306.476[2], sedangkan jumlah kambing khusus di Nusa Tenggara Barat sebanyak 678.769[3].

Kesehatan ternak merupakan faktor paling penting dalam pembudidayaan ternak. Pengendalian penyakit adalah usaha dalam mengendalikan penyakit yang bersifat menular maupun tidak menular dengan cara melakukan tindakan pencegahan dan pengobatan yang sesuai dengan prosedur terkait penyakit yang diderita. Penanganan penyakit yang salah akan menyebabkan meluasnya penularan hingga menyebabkan endemik pada penyakit tertentu[4].
Untuk kelompok binaan yang ingin berkonsultasi dengan pihak Unit Pelaksana Teknis Pembibitan Ternak dan Hijauan Makanan Ternak (UPT dan HMT) harus menghubungi instansi tersebut kemudian dokter akan datang melakukan pengecekan. Hal ini kurang efektif mengingat jauhnya jarak, lamanya waktu tempuh dan banyaknya jumlah hewan yang dikontrol oleh instansi tersebut[5]. Oleh karena itu dibutuhkan suatu sistem yang diharapkan mampu menyelesaikan permasalahan khususnya pada kambing di mana sistem tersebut dapat menirukan keahlian pakar.

Sistem pakar adalah sistem yang berusaha mengadopsi pengetahuan manusia ke komputer yang dirancang untuk memodelkan kemampuan menyelesaikan masalah seperti layaknya seorang pakar[6]. Ada beberapa metode yang dapat digunakan dalam sistem pakar seperti Certainty Factor untuk menghitung ketidak pastian, dan Forward Chaining sebagai mesin inferensi.

Forward Chaining adalah metode pencarian atau teknik pelacakan yang dimulai dengan informasi yang ada penggabungan rule untuk menghasilkan suatu 
kesimpulan atau tujuan. Forward Chaining merupakan metode inferensi yang melakukan penalaran dari suatu masalah kepada solusinya[7]. Metode Certainty Factor adalah metode yang mendefinisikan kepastian terhadap sebuah fakta untuk menggambarkan tingkat keyakinan pakar, sehingga akan didapatkan persentase keyakinan terhadap penyakit yang diderita berdasarkan dari proses perhitungan yang diambil dari nilai bobot[5].

\section{TINJAUAN PUSTAKA}

\subsection{Tinjauan Pustaka}

Terdapat beberapa penelitian yang digunakan sebagai sumber rujukkan dalam penelitian ini. Penelitian tentang sistem pakar diagnosis penyakit pada kambing dengan metode Dempster Shafer menggunakan 11 data jenis penyakit serta 32 gejala penyakit pada kambing. Berdasarkan hasil pengujian terhadap jumlah data menghasilkan nilai akurasi sebesar 94\%[8]. Penelitian tentang implementasi metode Naïve Bayes untuk diagnosis penyakit pada kambing dengan menggunakan 9 data jenis penyakit. Hasil pengujian sistem dengan metode Naïve Bayes sebesar $90 \%$. Kekurangan penelitian ini yaitu sistem hanya dapat memasukkan 4 input saja[6].

Penelitian tentang sistem diagnosis penyakit pada kambing menggunakan metode Forward Chaining digunakan untuk mendiagnosis sebanyak 16 penyakit dan 43 gejala penyakit pada kambing. Sistem pakar untuk mendiagnosis penyakit pada kambing sudah berhasil mendeteksi ke-16 jenis penyakit dengan akurasi mencapai $100 \%$. Pada penelitian selanjutnya dapat menggabungkan metode Forward Chaining dengan pembobotan Certainty Factor untuk menghasilkan keputusan yang lebih pasti[1].

Penelitian tentang pengembangan sistem pakar diagnosa penyakit pada kambing menggunakan metode Forward Chaining berbasis Android. Sistem ini dibangun untuk mendiagnosa sebanyak 7 data penyakit dan 26 gejala. Aplikasi sistem pakar dengan metode Forward Chaining berbasis Android dapat membuat kesimpulan jenis penyakit berdasarkan masukan 2-3 gejala dengan tingkat akurasi mencapai $100 \%$. Pada penelitian selanjutnya, diharapkan dapat menggabungkan metode lain untuk mendapatkan perhitungan nilai akurasi yang lebih baik[9].

Penelitian tentang sistem pakar diagnosis penyakit pada kambing menggunakan metode Certainty Factor digunakan untuk mendiagnosis 10 jenis penyakit yang diderita kambing. Sistem ini dibangun dengan bahasa pemrograman web PHP dan MySQL sebagai database nya. Uji coba sistem pada 25 kasus untuk pakar 1 menghasilkan tingkat akurasi sebesar $84 \%$ dan pakar 2 menghasilkan tingkat akurasi sebesar $80 \%$. Sistem mengeluarkan konklusi yang memiliki nilai di atas atau sama dengan 70\%[4]. Adapun kekurangan dari sistem ini yaitu sistem tidak bisa diakses di mana saja karena membutuhkan koneksi internet, serta hanya menggunakan 2 orang pakar.

Penelitian mengenai sistem pakar untuk mendiagnosa penyakit pada ayam dengan metode Certainty Factor berbasis Android. Pada penelitian ini data penyakit sebanyak 19 jenis penyakit pada ayam dengan 78 jenis gejala. Dalam pengujian diagnosa antara perhitungan sistem dengan secara manual, didapatkan tingkat kesesuaiannya telah mencapai 99\%[10]. Adapun kekurangan dari sistem ini yaitu data penyakit ayam dibatasi hanya pada penyakit yang disebabkan oleh bakteri.

Penelitian mengenai penerapan metode Certainty Factor dalam sistem pakar pendeteksi resiko Osteoporosis dan Osteoarthritis. Dengan presentasi keakuratan $80 \%$ menjadi bukti bahwa diagnosa gejala setiap pakar mempengaruhi tingkat keakuratan sistem sehingga untuk menghindari hal ini jika melibatkan lebih dari satu pakar, pakar-pakar tersebut harus mendiskusikan gejala yang tepat sehingga keakuratan sistem memiliki presentase yang lebih baik. Pada penelitian ini, untuk daftar gejala hanya melibatkan satu orang pakar, sedangkan satu pakar lainnya sebagai penguji terhadap proses validasi aplikasi ini[11].

Selain beberapa penelitian mengenai penyakit pada kambing terdapat juga penelitian terdahulu mengenai sistem pakar dengan menggunakan metode Forward Chaining dan Certainty Factor. Penelitian tentang penerapan metode Forward Chaining dan Certainty Factor pada sistem pakar diagnosa hama anggrek coelogyne pandurate. Pada penelitian ini terdapat 12 jenis hama dan 18 gejala yang digunakan. Berdasarkan hasil perhitungan, maka keterangan tingkat keyakinan berdasarkan tabel interpretasi dari pakar dan persentase akhir sebesar 93,0736\% adalah sangat mungkin kedua metode ini diterapkan untuk menyelesaikan masalah yang ada[12].

Penelitian tentang pendeteksi gangguan jaringan lokal menggunakan metode Certainty Factor dengan menggunakan inferensi Forward Chaining. Metode Certainty Factor dapat diimplementasikan pada aplikasi sistem pakar pendeteksi gangguan jaringan lokal dengan tingkat akurasi sebesar 92\% dari nilai ratarata Certainty Factor sebanyak 17 gangguan[13].

Penelitian mengenai analisis perbandingan metode Certainty Factor, Dempster Shafer dan 
Teorema Bayes untuk mendiagnosa penyakit inflamasi dermatitis imun pada anak. Pada penelitian membahas tentang jenis penyakit inflamasi dermatitis imun pada anak yang teridiri dari Eksim Dermatitis, Psoriasis, dan Atopik. Hasil yang didapatkan yaitu bahwa tingkat akurasi sistem dengan menggunakan metode Certainty Factor memiliki nilai probabilitas yanga lebih tinggi yaitu sebesar $80 \%$ dibandingkan dengan nilai probabilitas metode metode Dempster Shafer yaitu sebesar $60 \%$ dan metode Teorema Bayes sebesar $51 \%[14]$.

Berdasarkan tinjauan pustaka dari penelitian yang pernah dilakukan, maka penulis ingin membuat suatu sistem pakar yang dapat mendiagnosis penyakit pada kambing dengan menggunakan metode Forward Chaining untuk menentukan rules-rules terhadap suatu penyakit berdasarkan gejala-gejala yang ada untuk mendapatkan suatu kesimpulan, dan metode Certainty Factor untuk mengetahui besarnya kemungkinan terjadinya gejala terhadap suatu penyakit yang diderita oleh kambing. Sistem pakar diagnosis 14 jenis penyakit pada kambing ini dibangun dengan menggunakan platform Android.

\subsection{Dasar Teori}

\section{a. Sistem Pakar}

Sistem pakar adalah salah satu kecerdasan buatan yang mengadopsi pengetahuan, fakta dan teknik penalaran pakar yang digunakan untuk memecahkan permasalahan yang biasanya hanya dapat dipecahkan oleh pakar dalam bidang tersebut[15]. Struktur sistem pakar terdiri dari dua pokok yaitu lingkungan pengembang (development environment) dan lingkungan konsultasi (consultation environment)[16].

b. Metode Forward Chaining

Forward chaining adalah metode inferensi maju dengan mekanisme berfikir pola-pola penalaran yang digunakan oleh sistem untuk mencapai suatu kesimpulan. Penalaran dimulai dengan mencocokkan kaidah-kaidah dalam basis pengetahuan dengan faktafakta yang ada dalam basis data[9]. Penelusuran dalam forward chaining dimulai dari fakta (gejala penyakit pada kambing) yang diketahui, kemudian mencocokkan fakta-fakta tersebut melalui rules yang ada untuk menuju kesimpulan (penyakit yang diderita). Gambaran dari penelusuran yang dilakukan metode forward chaining dapat dilihat pada Gambar 1.

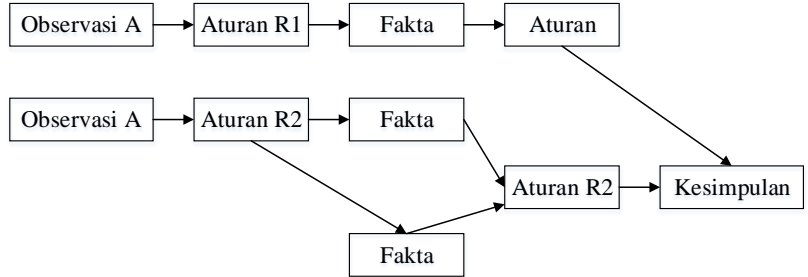

Gambar 1. Alur penelusuran metode forward chaining c. Certainty Factor

Certainty Factor adalah suatu metode untuk membuktikan apakah suatu fakta itu pasti atau tidak pasti yang berbentuk metric yang biasanya digunakan dalam sistem pakar. Metode ini sangat cocok untuk sistem pakar yang mendiagnosis sesuatu yang belum pasti[17]. Perhitungan nilai Certainty Factor dilakukan dengan membandingkan dua perhitungan saja, jika lebih akan dilakukan perhitungan secara bertahap. Nilai hasil metode Certainty Factor yang memiliki hasil mendekati 1 memiliki nilai kepercayaan yang terbesar. Certainty theory menggunakan suatu nilai yang disebut Certainty Factor (CF) untuk mengasumsikan derajat keyakinan seorang pakar terhadap suatu data[18]. Teori Certainty Factor (CF) diusulkan oleh Shortlife dan Buchanan pada 1975 untuk mengakomodasi ketidakpastian pemikiran seorang pakar. Perhitungan rule Certainty Factor dapat dipresentasikan sebagai berikut[19]:

$$
\begin{gathered}
\text { IF E1 AND E2 ...AND En THEN H (CF Rule) } \\
\text { atau } \\
\text { IF E1 AND E2 ...OR En THEN H (CF Rule) }
\end{gathered}
$$

Bentuk dasar rumus Certainty Factor dengan satu premis ditunjukkan seperti persamaan (3) sebagai berikut:.

$$
\begin{aligned}
C F(h, e) & =C F[e] * C F[\text { rule }] \\
& =C F[\text { user }] * C F[\text { pakar }]
\end{aligned}
$$

Perhitungan Certainty Factor gabungan dengan evidence kombinasi dua buah rule dengan evidence berbeda (E1 dan E2), tetapi hipotesis sama adalah sebagai berikut:

1. Apabila kedua nilai CF bernilai positif (CF1 $>0$ dan $\mathrm{CF} 2>0$ )

$C F_{\text {COMBINE }}(C F 1, C F 2)=C F 1+C F 2(1-C F 1)$

2. Apabila kedua nilai CF bernilai negatif (CF1 $<0$ dan CF2 $<0$ )

$$
C F_{\text {COMBINE }}(C F 1, C F 2)=C F 1+C F 2(1+C F 1)
$$


3. Apabila salah satu dari nilai CF bernilai negatif

$$
\begin{aligned}
C F_{\text {COMBINE }}(C F 1, C F 2)= & (C F 1+C F 2) / 1- \\
& (\min [|C F 1|,|C F 2|])
\end{aligned}
$$

Certainty Factor untuk hasil akhir persentase dapat dilihat pada persamaan (7) sebagai berikut:

\section{Persentase keyakinan $=C F C O M B I N E \times 100 \%$}

Pembuatan sistem pakar ini menggunakan teknik wawancara ahli dengan menginterpretasi "term" dari pakar yang selanjutnya diubah menjadi nilai CF tertentu. Nilai CF dapat dilihat pada Tabel I[19]:

TABEL I. NILAI EVIDANCE TINGKAT KEYAKINAN PAKAR.

\begin{tabular}{|c|c|}
\hline Nilai CF & Frase \\
\hline-1.0 & Pasti tidak \\
\hline-0.8 & Hampir pasti tidak \\
\hline-0.6 & Kemungkinan besar tidak \\
\hline-0.4 & Mungkin tidak \\
\hline-0.2 Sampai 0.2 & Tidak tahu \\
\hline 0.4 & Mungkin \\
\hline 0.6 & Kemungkinan besar \\
\hline 0.8 & Hampir pasti \\
\hline 1.0 & Pasti \\
\hline
\end{tabular}

d. Penyakit pada Kambing

Dalam penelitian ini, digunakan 14 jenis penyakit pada kambing yang diperoleh berdasarkan hasil wawancara bersama pakar selama proses penelitian ini berlangsung. Adapun 14 jenis penyakit yang digunakan yaitu Brucellosis, Mastitis, Bisul (Lumpy Jaw), Penyakit Kuku (Foot Root), Antraks, Pneumonia, Orf, Pink Eye, Scabies (Gudigan/Gatal), Kutu, Kembung, Diare, Keracunan, Kencing Batu.

e. Android

Android adalah sistem operasi bergerak (mobile operating system) yang mengadopsi sistem operasi linux, namu telah dimodifikasi. Google menginginkan agar Android bersifat terbuka dan gratis, oleh karena itu hampir setiap kode program Android diluncurkan berdasarkan lisensi open-source Apache yang berarti bahwa semua orang yang ingin menggunakan Android dapat men-download penuh source code-nya[20].

\section{Metode Penelitian}

\subsection{Data}

Data yang dibutuhkan dalam pembangunan sistem pakar diagnosis penyakit pada kambing adalah data deskripsi dan gejala penyakit yang diderita oleh kambing, data bobot nilai kepercayaan pakar terhadap gejala penyakit yang diderita kambing, dan data penanganan atau solusi serta pencegahan oleh pakar yang dapat dilakukan ketika kambing terdiagnosis mengalami suatu penyakit.

\subsection{Proses Penelitian}

Penelitian sistem pakar diagnosis penyakit pada kambing ini dilakukan melalui beberapa tahapan. Berikut adalah penjelasan mengenai langkah-langkah penelitian yang dilakukan untuk membangun sistem pakar diagnosis penyakit pada kambing, diantaranya:.

a. Studi Literatur

Studi literatur dilakukan dengan mengumpulkan sumber-sumber keilmuan yang mendukung penelitian berkaitan dengan penyakit pada kambing dan metode Forward Chaining serta Certainty Factor pada buku, jurnal, skripsi maupun sumber lain yang terdahulu guna mengetahui kelebihan serta kekurangannya, yang dapat menjadi acuan untuk pengembangan sistem ini.

b. Pengumpulan Data

Tahapan pengumpulan data dilakukan dengan melakukan wawancara dengan pakar hewan sebelum dan selama proses pembangunan sistem. Proses wawancara sebelum pembangunan sistem dimaksudkan untuk mengetahui penyakit pada kambing yang disebabkan oleh bakteri, virus dan parasit serta penyakit metabolik, sedangkan proses wawancara selama pembangunan sistem berlangsung dimaksudkan untuk melengkapi data yang dibutuhkan selama penelitian. Pakar dalam penelitian ini yaitu dokter hewan yang berjumlah 3 orang yaitu drh. Made Sriasih, M. Agr, Sc., Ph.D., drh. Kholik, M.Vet. dan drh. Novarina S.I.N., M.Si. Adapun data yang didapatkan selama proses penelitian ini dilakukan berupa data nilai CF gejala penyakit pada kambing yang dapat dilihat pada lampiran 1, serta data saran penanganan dan pencegahan penyakit pada kambing.

c. Perancangan Sistem

Perancangan sistem berupa perancangan arsitektur sistem serta perancangan desain sistem. Sistem pakar terdiri dari dua lingkuan, yaitu lingkungan pengembangan dipakai pengembang untuk mengenalkan pengetahuan kepada basis pengetahuan dan lingkungan konsultasi yang digunakan user untuk mendapatkan suatu pengetahuan pakar. Arsitektur sistem pakar diagnosis penyakit pada kambing akan dijelaskan melalui diagram seperti Gambar 2. 


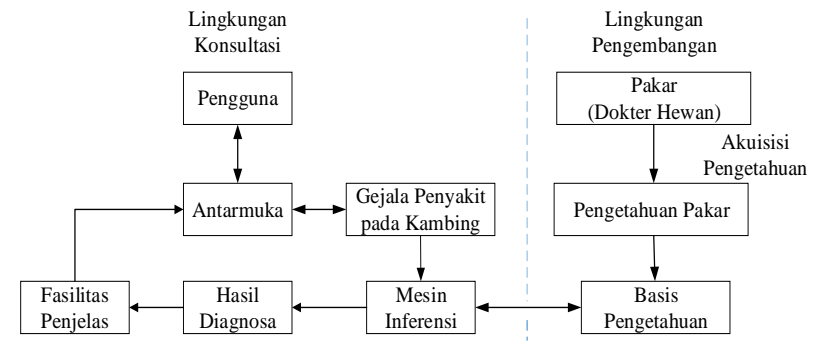

Gambar 2. Arsitektur sistem pakar diagnosis penyakit pada kambing[21].

Berdasarkan Gambar 2 dapat dijelaskan desain arsitektur sistem pakar diagnosis penyakit ada kambing sebagai berikut:

1. Pengguna, yaitu peternak sebagai pengguna yang menggunakan aplikasi sistem pakar untuk melakukan konsultasi penyakit pada hewan ternak mereka (kambing).

2. Antarmuka (interface), merupakan mekanisme yang digunakan antara pengguna (peternak) dan sistem. Interface atau antarmuka memudahkan pengguna untuk berkomunikasi dengan sistem, di mana pengguna (peternak) menerima informasi dari interface yang disajikan pada halaman aplikasi.

3. Gejala pada Kambing, merupakan data yang akan digunakan untuk penentu hasil akhir dari diagnosis penyakit pada kambing di mana pengguna akan memilih data gejala yang ada.

4. Hasil Diagnosis, merupakan hasil akhir atau kesimpulan dari data gejala yang telah diinputkan pengguna dan diproses oleh sistem.

5. Mesin Inferensi, merupakan bagian terpenting dalam sistem pakar atau dapat disebut juga sebagai otak dari sistem pakar yang berfungsi untuk memandu dalam proses penalaran sistem. Pada sistem ini metode inferensi yang digunakan yaitu Forward Chaining. Forward Chaining adalah teknik pencarian yang dimulai dengan fakta yang diketahui, kemudian mencocokkan fakta-fakta tersebut dengan bagian IF dari rules IF-THEN. Bila ada fakta yang cocok dengan bagian IF, maka rule tersebut dieksekusi.

6. Fasilitas penjelas, Fasilitas penjelas berfungsi untuk memberikan penjelasan kepada pengguna mengenai suatu kesimpulan yang dapat diambil. Sistem ini akan memberikan penjelasan mengenai jenis penyakit yang dialami kambing, persentase keyakinan serta saran penanganan dan pencegahan yang dapat dilakukan.

7. Pakar (dokter hewan), berperan untuk memberikan pengetahuan atau informasi dan data mengenai penyakit pada kambing yang berupa data gejala, saran penanganan dan pencegahan serta bobot nilai kepercayaan pada masing-masing gejala.

8. Pengetahuan pakar, Pengetahuan pakar yang ada dapat direpresentasian ke dalam basis pengetahuan untuk dijadikan dasar pembentukan aturan pada sistem yang akan dibangun.

9. Basis pengetahuan, merupakan pengetahuan dan pemahaman yang dimiliki oleh pakar yang ada dalam data sistem. Basis pengetahuan mengandung kumpulan pengetahuan berupa fakta dan aturan yang diperoleh dari pakar maupun sumber data lain untuk menyelesaikan masalah.

10. Akuisisi pengetahuan, pengumpulan dan transformasi keahlian dalam menyelesaikan masalah dari pengetahuan pakar ke dalam program komputer yang selanjutnya ditransfer ke dalam basis pengetahuan.

d. Implementasi

Implementasi merupakan proses pengimplementasian rancangan sistem yang ada ke dalam sebuah program. Implementasi sistem membahas tentang tampilan dari sistem pakar diagnosis penyakit pada kambing. Halaman konsultasi akan menampilkan seluruh gejala penyakit pada kambing yang tersimpan dalam sistem untuk digunakan oleh pengguna melakukan konsultasi. Setelah pengguna telah selesai memilih gejala, selanjutnya pengguna dapat memilih tombol diagnosis untuk mengetahui hasil diagnosis sistem. Terdapat halaman hasil diagnosis, dimana halaman ini akan ditampilkan setelah pengguna memilih gejala dan menekan tombol diagnosis. Halaman hasil diagnosis ini menampilkan persentase dan kemungkinan penyakit yang diderita kambing. Selain itu, akan menampilkan gejala-gejala yang telah dipilih oleh pengguna.

e. Pengujian Sistem

Pengujian sistem dilakukan untuk mengetahui kesesuaian hasil dari sistem serta kelayakan dari sistem yang telah dibuat. Pengujian yang dilakukan berupa pengujian akurasi sistem, pengujian black box, pengujian perhitungan teoritis dan pengujian MOS (Mean Opinion Score).

f. Penarikan Kesimpulan

Penarikan kesimpulan didapatkan dari hasil dari pengujian sistem yang dilakukan. Kesimpulan didapat berdasarkan kesesuaian sistem yang dibangun dengan tujuan penelitian dan telah 
mampu memberikan informasi yang sesuai pengguna sistem.

\section{Hasil dan PEMbahasan}

\subsection{Teknik Pengujian Sistem}

Pengujian sistem dilakukan untuk mengetahui kesesuaian hasil yang diberikan oleh sistem serta kelayakan dari sistem pakar yang dibangun.

\subsubsection{Pengujian Black Box}

Pengujian black box berfungsi untuk menguji fungsionalitas dari sistem pakar diagnosis penyakit pada kambing dengan metode Forward Chaining dan Certainty Factor. Pengujian black box sistem pakar diagnosis penyakit pada kambing ini dilakukan oleh 5 orang responden mahasiswa Teknik Informatika Universitas Mataram sebagai pengguna android telah berjalan sebagaimana mestinya.

\subsubsection{Pengujian dengan Perhitungan Teoritis}

Misalkan diketahui ternak mengalami gejala seperti pada Tabel II.

TABEL II. CONTOH KASUS PERHITUNGAN TEORITIS

\begin{tabular}{|c|c|c|c|}
\hline Gejala & $\begin{array}{c}\text { CF } \\
\text { Pakar }\end{array}$ & CF User & Penyakit \\
\hline $\begin{array}{c}\text { Perubahan warna air susu } \\
\text { yang abnormal (G7) }\end{array}$ & 0.93 & 0.4 & Mastitis \\
\hline $\begin{array}{l}\text { Ternak terlihat kurus } \\
\text { (G16) }\end{array}$ & 0.53 & 0.8 & $\begin{array}{c}\text { Penyakit kuku } \\
\text { (Foot Root) }\end{array}$ \\
\hline $\begin{array}{c}\text { Perubahan warna air susu } \\
\text { yang abnormal (G7) }\end{array}$ & 0.66 & 0.4 & Antraks \\
\hline $\begin{array}{l}\text { Ternak terlihat kurus } \\
\text { (G16) }\end{array}$ & 0.73 & 0.8 & \multirow{4}{*}{$\begin{array}{c}\text { Scabies } \\
\text { (Gudigan/ } \\
\text { Gatal) }\end{array}$} \\
\hline Gatal pada kulut (G41) & 1.0 & 1.0 & \\
\hline $\begin{array}{c}\text { Penebalan pada bagian } \\
\text { kulit yang gatal (G42) }\end{array}$ & 1.0 & 0.8 & \\
\hline $\begin{array}{c}\text { Produktivitas menurun } \\
\text { (G44) }\end{array}$ & 0.66 & 0.8 & \\
\hline $\begin{array}{l}\text { Ternak terlihat kurus } \\
\text { (G16) }\end{array}$ & 0.6 & 0.8 & Kutu \\
\hline
\end{tabular}

Pada Tabel II dapat dilihat bahwa terdapat 5 gejala penyakit pada kambing yang dialami ternak. Setelah gejala tersebut diketahui, selanjutnya mesin inferensi yakni forward chaining mulai bekerja melakukan proses penalaran yakni dengan mencari tahu kemungkinan penyakit yang bisa terjadi dari setiap gejala yang dipilih, beserta bobot dari masing-masing gejala pada setiap penyakit berdasarkan basis pengetahuan yang tersimpan. Setelah diketahui penyakit dan bobot dari masing-masing gejala pada setiap penyakit, selanjutnya dilakukan proses perhitungan dengan metode Certainty Factor di mana setiap gejala dihitung dengan menggunakan rumus pada Persamaan (3), sampai dengan (7) berdasarkan bobot masing-masing gejala untuk memperoleh kesimpulan hasil diagnosis berupa penyakit yang diderita beserta persentase kemungkinan terjadinya penyakit. Berikut proses perhitungan dengan metode Certainty Factor. a. Penyakit Mastitis

- Menghitung nilai CF Gejala 7:

$C F[H, E] 1=C F($ user $) \times C F($ pakar $)$

$C F[H, E] 1=0.4 \times 0.93$

$C F[H, E] 1=0.37$

b. Penyakit Kuku (Foot Root)

- Menghitung nilai CF Gejala 16:

$C F[H, E] 1=C F($ user $) \times C F($ pakar $)$

$C F[H, E] 1=0.8 \times 0.53$

$C F[H, E] 1=0.42$

c. Penyakit Antraks

- Menghitung nilai CF Gejala 7:

$C F[H, E] 1=C F($ user $) \times C F($ pakar $)$

$C F[H, E] 1=0.4 \times 0.66$

$C F[H, E] 1=0.26$

d. Penyakit Scabies (Gudigan/Gatal)

- Menghitung nilai CF Gejala 16:

$C F[H, E] 1=C F($ user $) \times C F($ pakar $)$

$C F[H, E] 1=0.8 \times 0.73$

$C F[H, E] 1=0.58$

- Menghitung nilai CF Gejala 41:

$C F[H, E] 2=C F($ user $) \times C F($ pakar $)$

$C F[H, E] 2=1.0 \times 1.0$

$C F[H, E] 2=1.0$

- Menghitung nilai CF Gejala 42:

$C F[H, E] 3=C F($ user $) \times C F($ pakar $)$

$C F[H, E] 3=0.8 \times 1.0$

$C F[H, E] 3=0.8$

- Menghitung nilai CF Gejala 44:

$C F[H, E] 4=C F($ user $) \times C F($ pakar $)$

$C F[H, E] 4=0.8 \times 0.66$

$C F[H, E] 4=0.52$

- Menghitung nilai CF gabungan $\mathrm{CF}[\mathrm{H}, \mathrm{E}] 1$, $\mathrm{CF}[\mathrm{H}, \mathrm{E}] 2$ :

CF combine $C F 1,2=C F 1+C F 2(1-C F 1)$

CF combine $C F 1,2=0.58+1.0(1-0.58)$

$C F$ combine $C F 1,2=1.0 \rightarrow$ menjadi nilai $C F$ baru $\left(C F_{b 1}\right)$

- Menghitung nilai $\mathrm{CF}$ gabungan $\mathrm{CF}_{\text {combine }} \mathrm{CF}_{\mathrm{b} 1}$, $\mathrm{CF}[\mathrm{H}, \mathrm{E}] 3$ :

CF combine $C F_{b 1}, 3=C F_{b 1}+C F 3\left(1-C F_{b 1}\right)$

$C F$ combine $C F_{b 1}, 3=1.0+0.8(1.0-1.0)$

$C F$ combine $C F_{b 1}, 3=1.0$

$\rightarrow$ menjadi nilai $C F$ baru $\left(C F_{b 2}\right)$

- Menghitung nilai $\mathrm{CF}$ gabungan $\mathrm{CF}_{\text {combine }} \mathrm{CF}_{\mathrm{b} 2 \text {, }}$ $\mathrm{CF}[\mathrm{H}, \mathrm{E}] 4$ :

CF combine $C F_{b 2}, 4=C F_{b 2}+C F 4\left(1-C F_{b 2}\right)$

CF combine $C F_{b 2}, 4=1.0+0.52(1.0-1.0)$

$C F$ combine $C F_{b 2}, 4=1.0$

e. Penyakit Kutu

- Menghitung nilai CF Gejala 16:

$C F[H, E] 1=C F($ user $) \times C F($ pakar $)$

$C F[H, E] 1=0.8 \times 0.6$

$C F[H, E] 1=0.48$ 
Berdasarkan 5 gejala yang telah di-inputkan pengguna, maka didapatkan nilai CF yang paling tinggi yaitu pada penyakit Scabies (Gudigan/ Gatal) dengan nilai CF sebesar 1.0 atau dengan persentase sebesar $100 \%$.

Gambar 5 merupakan tampilan hasil diagnosis sistem pakar penyakit pada kambing jika di-inputkan 5 gejala pada Tabel I. Hasil yang ditampilkan adalah ternak mengidap penyakit Scabies (Gudigan/ Gatal) dengan persentase kemungkinan sebesar 100\%, dimana hal ini membuktikan bahwa hasil perhitungan teoritis sesuai dengan hasil diagnosis dari sistem pakar.

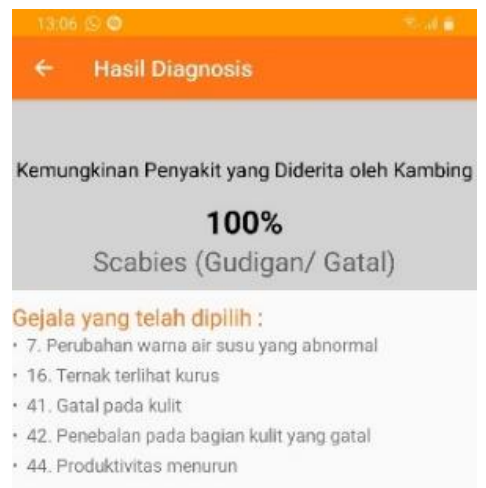

Gambar 5. Hasil pengujian perhitungan metode Certainty Factor pada sistem

\section{A.3. Pengujian Akurasi Sistem}

Pengujian akurasi sistem pakar diagnosis penyakit pada kambing dilakukan oleh 3 orang pakar dokter hewan. Pengujian ini bertujuan untuk mengetahui kesesuaian antara hasil diagnosis pakar dan hasil diagnosis sistem berdasakan 30 contoh kasus yang diujikan kepada pakar.

Dalam pengujian contoh kasus ditampilkan beberapa gejala yang dirasakan oleh ternak dan daftar kemungkinan penyakit yang diderita. Data gejala dan penyakit yang terdapat pada form pengujian telah sesuai dengan data yang telah tersimpan dalam basis pengetahuan, dimana data tersebut diperoleh dari pakar. Selanjutnya pakar (dokter hewan) diminta untuk mendiagnosis kasus tersebut. Kasus yang diujikan pada pakar akan diujikan juga ke dalam sistem. Gejala-gejala di masukkan ke dalam sistem, selanjutnya mesin inferensi (forward chaining) mulai bekerja dengan melakukan penelusuran informasi berupa mencari tahu kemungkinan penyakit yang diderita beserta bobotnya berdasarkan gejala yang telah dimasukkan. Setelah semua informasi kemungkinan penyakit dan bobot diperoleh, kemudian dilakukan proses perhitungan dengan menggunakan metode certainty factor untuk memperoleh kesimpulan berupa hasil diagnosis penyakit beserta persentase kemungkinannya.
Pengujian akurasi sistem dilakukan dengan dua cara yaitu perhitungan akurasi berdasarkan nilai CF (bobot) masing-masing pakar dan nilai CF (bobot) rata-rata ketiga pakar. Hasil pengujian akurasi dari pakar dan hasil pengujian dari sistem disajikan dalam bentuk tabel pada Tabel II, Tabel III, Tabel IV dan Tabel V.

- Pengujian akurasi berdasarkan bobot rata-rata

TABEL III. HASIL PENGUJIAN DENGAN Bobot RATA-RATA

\begin{tabular}{|c|c|c|c|}
\hline $\begin{array}{l}\text { Hasil diagnosis } \\
\text { sistem }\end{array}$ & $\begin{array}{c}\text { Hasil } \\
\text { diagnosis P1 }\end{array}$ & $\begin{array}{c}\text { Hasil } \\
\text { diagnosis P2 }\end{array}$ & $\begin{array}{c}\text { Hasil } \\
\text { diagnosis P3 }\end{array}$ \\
\hline Mastitis (100\%) & Mastitis & Mastitis & Mastitis \\
\hline $\begin{array}{c}\text { Brucellosis } \\
(100 \%)\end{array}$ & Brucellosis & Brucellosis & Brucellosis \\
\hline $\begin{array}{c}\text { Bisul (Lumpy } \\
\text { Jaw) (93\%) }\end{array}$ & $\begin{array}{c}\text { Bisul (Lumpy } \\
\text { Jaw) }\end{array}$ & $\begin{array}{c}\text { Bisul (Lumpy } \\
\text { Jaw) }\end{array}$ & $\begin{array}{c}\text { Bisul (Lumpy } \\
\text { Jaw) }\end{array}$ \\
\hline $\begin{array}{c}\text { Penyakit Kuku } \\
\text { (Foot Root) } \\
(100 \%)\end{array}$ & $\begin{array}{l}\text { Penyakit kuku } \\
\text { (Foot Root) }\end{array}$ & $\begin{array}{c}\text { Penyakit } \\
\text { Kuku (Foot } \\
\text { Root) }\end{array}$ & $\begin{array}{c}\text { Penyakit } \\
\text { Kuku (Foot } \\
\text { Root) }\end{array}$ \\
\hline Antraks (99\%) & Antraks & Antraks & Antraks \\
\hline $\begin{array}{c}\text { Pneumonia } \\
(100 \%)\end{array}$ & Pneumonia & Pneumonia & Pneumonia \\
\hline $\operatorname{Orf}(100 \%)$ & Orf & Orf & Orf \\
\hline $\begin{array}{c}\text { Pink Eye } \\
\text { (Radang Selaput } \\
\text { Mata) }(100 \%)\end{array}$ & $\begin{array}{c}\text { Pink Eye } \\
\text { (Radang } \\
\text { Selaput Mata) }\end{array}$ & $\begin{array}{c}\text { Pink Eye } \\
\text { (Radang } \\
\text { Selaput } \\
\text { Mata) }\end{array}$ & $\begin{array}{c}\text { Pink Eye } \\
\text { (Radang } \\
\text { Selaput } \\
\text { Mata) }\end{array}$ \\
\hline $\begin{array}{c}\text { Scabies } \\
\text { (Gudigan/ } \\
\text { Gatal) }(100 \%) \\
\end{array}$ & $\begin{array}{c}\text { Scabies } \\
\text { (Gudigan/ } \\
\text { Gatal) }\end{array}$ & $\begin{array}{c}\text { Scabies } \\
\text { (Gudigan/ } \\
\text { Gatal) }\end{array}$ & $\begin{array}{c}\text { Scabies } \\
\text { (Gudigan/ } \\
\text { Gatal) }\end{array}$ \\
\hline Kutu (99\%) & Kutu & Kutu & Kutu \\
\hline $\begin{array}{c}\text { Kembung } \\
(100 \%)\end{array}$ & Kembung & Kembung & Kembung \\
\hline Diare (100\%) & Diare & Diare & Diare \\
\hline $\begin{array}{c}\text { Keracunan } \\
(100 \%)\end{array}$ & Keracunan & Keracunan & Keracunan \\
\hline $\begin{array}{c}\text { Kencing Batu } \\
(100 \%)\end{array}$ & Kencing Batu & Kencing Batu & Kencing Batu \\
\hline Mastitis (100\%) & Mastitis & Mastitis & Mastitis \\
\hline $\begin{array}{c}\text { Scabies } \\
\text { (Gudigan/ } \\
\text { Gatal) }(66 \%)\end{array}$ & Kembung & Kembung & Kembung \\
\hline $\begin{array}{c}\text { Bisul (Lumpy } \\
\text { Jaw) (87\%) }\end{array}$ & $\begin{array}{c}\text { Bisul (Lumpy } \\
\text { Jaw) }\end{array}$ & $\begin{array}{c}\text { Bisul (Lumpy } \\
\text { Jaw) }\end{array}$ & $\begin{array}{c}\text { Bisul (Lumpy } \\
\text { Jaw) }\end{array}$ \\
\hline $\begin{array}{c}\text { Penyakit Kuku } \\
\text { (Foot Root) } \\
(100 \%)\end{array}$ & $\begin{array}{l}\text { Penyakit kuku } \\
\text { (Foot Root) }\end{array}$ & $\begin{array}{c}\text { Penyakit } \\
\text { Kuku (Foot } \\
\text { Root) }\end{array}$ & $\begin{array}{c}\text { Penyakit } \\
\text { Kuku (Foot } \\
\text { Root) }\end{array}$ \\
\hline Antraks (98\%) & Antraks & Keracunan & Antraks \\
\hline $\begin{array}{c}\text { Pneumonia } \\
(100 \%)\end{array}$ & Pneumonia & Pneumonia & Pneumonia \\
\hline $\begin{array}{c}\text { Penyakit Kuku } \\
\text { (Foot Root) } \\
(74 \%) \\
\end{array}$ & Orf & Bisul & Orf \\
\hline $\begin{array}{c}\text { Pink Eye } \\
\text { (Radang Selaput } \\
\text { Mata) }(97 \%)\end{array}$ & $\begin{array}{c}\text { Pink Eye } \\
\text { (Radang } \\
\text { Selaput Mata) }\end{array}$ & $\begin{array}{c}\text { Pink Eye } \\
\text { (Radang } \\
\text { Selaput } \\
\text { Mata) }\end{array}$ & $\begin{array}{c}\text { Pink Eye } \\
\text { (Radang } \\
\text { Selaput } \\
\text { Mata) }\end{array}$ \\
\hline
\end{tabular}


TABEL IV. LANJUt HASIL PENGUJIAN DENGAN BOBOt RATA-

\begin{tabular}{|c|c|c|c|}
\hline $\begin{array}{c}\text { Hasil diagnosis } \\
\text { sistem }\end{array}$ & $\begin{array}{c}\text { Hasil } \\
\text { diagnosis P1 }\end{array}$ & $\begin{array}{c}\text { Hasil } \\
\text { diagnosis P2 }\end{array}$ & $\begin{array}{c}\text { Hasil } \\
\text { diagnosis P3 }\end{array}$ \\
\hline $\begin{array}{c}\text { Scabies } \\
\text { (Gudigan/ } \\
\text { Gatal) }(80 \%)\end{array}$ & $\begin{array}{c}\text { Scabies } \\
\text { (Gudigan/ } \\
\text { Gatal) }\end{array}$ & Kutu & Kutu \\
\hline $\begin{array}{c}\text { Scabies } \\
\text { (Gudigan/ } \\
\text { Gatal) }(87 \%)\end{array}$ & Kutu & $\begin{array}{c}\text { Scabies } \\
\text { (Gudigan/ } \\
\text { Gatal) }\end{array}$ & Mastitis \\
\hline $\begin{array}{c}\text { Kembung } \\
(100 \%)\end{array}$ & Kembung & Kembung & Kembung \\
\hline $\begin{array}{c}\text { Diare (100\%) } \\
\text { Keracunan } \\
(99 \%)\end{array}$ & Diare & Diare & Diare \\
\hline $\begin{array}{c}\text { Kencing Batu } \\
(100 \%)\end{array}$ & Kencing Batu & Kencing Batu & Kencing Batu \\
\hline Diare (100\%) & Diare & Diare & Diare \\
\hline $\begin{array}{c}\text { Scabies } \\
\text { (Gudigan/ } \\
\text { Gatal) }(55 \%)\end{array}$ & Mastitis & Bisul & Mastitis \\
\hline Berdasarkanan & Keracunan \\
\hline
\end{tabular}

Berdasarkan hasil pengujian akurasi pada Tabel III dan Tabel IV diperoleh nilai akurasi berdasarkan bobot rata-rata pakar sebesar $85.55 \%$.

- Pengujian akurasi berdasarkan bobot masingmasing pakar

TABEL V. HASIL PENGuJIAN DENGAN Bobot PAKAR 1

\begin{tabular}{|c|c|c|}
\hline $\begin{array}{c}\text { Hasil diagnosis pakar } \\
1\end{array}$ & $\begin{array}{c}\text { Hasil diagnosis sistem } \\
\text { berdasarkan bobot pakar } \\
1\end{array}$ & Keterangan \\
\hline Mastitis & Mastitis (100\%) & Valid \\
\hline Brucellosis & Brucellosis (100\%) & Valid \\
\hline Bisul (Lumpy Jaw) & Bisul (Lumpy Jaw) (100\%) & Valid \\
\hline $\begin{array}{l}\text { Penyakit kuku (Foot } \\
\text { Root) }\end{array}$ & $\begin{array}{l}\text { Penyakit kuku (Foot Root) } \\
(100 \%)\end{array}$ & Valid \\
\hline Antraks & Antraks (100\%) & Valid \\
\hline Pneumonia & $\begin{array}{l}\text { Pneumonia, Kembung } \\
(100 \%)\end{array}$ & Valid \\
\hline Orf & $\operatorname{Orf}(100 \%)$ & Valid \\
\hline $\begin{array}{l}\text { Pink Eye (Radang } \\
\text { Selaput Mata) }\end{array}$ & $\begin{array}{l}\text { Pink Eye (Radang Selaput } \\
\text { Mata) }(100 \%)\end{array}$ & Valid \\
\hline Scabies & $\begin{array}{l}\text { Scabies (Gudigan/ Gatal) } \\
(100 \%)\end{array}$ & Valid \\
\hline Kutu & $\begin{array}{l}\text { Scabies (Gudigan/ Gatal), } \\
\text { Kutu (100\%) }\end{array}$ & Valid \\
\hline Kembung & Kembung (100\%) & Valid \\
\hline Diare & Diare (100\%) & Valid \\
\hline Keracunan & Keracunan (100\%) & Valid \\
\hline Kencing Batu & Kencing Batu (100\%) & Valid \\
\hline Mastitis & Mastitis (100\%) & Valid \\
\hline Kembung & Scabies (60\%) & Tidak Valid \\
\hline Bisul (Lumpy Jaw) & Bisul (Lumpy Jaw) (100\%) & Valid \\
\hline $\begin{array}{l}\text { Penyakit kuku (Foot } \\
\text { Root) }\end{array}$ & $\begin{array}{l}\text { Penyakit kuku (Foot Root) } \\
(100 \%)\end{array}$ & Valid \\
\hline Antraks & Antraks (100\%) & Valid \\
\hline Pneumonia & $\begin{array}{l}\text { Pneumonia, Kembung } \\
(100 \%)\end{array}$ & Valid \\
\hline
\end{tabular}

TABEL VI. LANJUtAN HASIL PENGUJIAN DENGAN BOBOT PAKAR 1

\begin{tabular}{|l|l|c|}
\hline \multicolumn{1}{|c|}{$\begin{array}{c}\text { Hasil diagnosis } \\
\text { pakar 1 }\end{array}$} & $\begin{array}{l}\text { Hasil diagnosis sistem } \\
\text { berdasarkan bobot pakar }\end{array}$ & Keterangan \\
\hline Orf & $\begin{array}{l}\text { Penyakit kuku (Foot Root) } \\
(80 \%)\end{array}$ & Tidak Valid \\
\hline $\begin{array}{l}\text { Pink Eye (Radang } \\
\text { Selaput Mata) }\end{array}$ & $\begin{array}{l}\text { Pink Eye (Radang Selaput } \\
\text { Mata) (92\%) }\end{array}$ & Valid \\
\hline Scabies & $\begin{array}{l}\text { Scabies (Gudigan/ Gatal) } \\
(80 \%)\end{array}$ & Valid \\
\hline Kutu & $\begin{array}{l}\text { Scabies (Gudigan/ Gatal) } \\
(84 \%)\end{array}$ & Tidak Valid \\
\hline Kembung & Kembung (100\%) & Valid \\
\hline Diare & Diare (100\%) & Valid \\
\hline Keracunan & Keracunan (100\%) & Valid \\
\hline Kencing Batu & Kencing Batu (100\%) & Valid \\
\hline Diare & Diare (100\%) & Valid \\
\hline Mastitis & $\begin{array}{l}\text { Scabies (Gudigan/ Gatal) } \\
(51 \%)\end{array}$ & Tidak Valid \\
\hline
\end{tabular}

Berdasarkan hasil pengujian akurasi pada Tabel $\mathrm{V}$ dan Tabel VI terdapat 30 contoh kasus yang dibandingkan dengan hasil diagnosis pakar 1, terdapat 26 kasus yang sesuai (valid). Sehingga diperoleh akurasi sebesar $\frac{26}{30} x 100 \%=86.66 \%$.

TABEL VII. HASIL PENGUJIAN DENGan Bobot PAKar 2

\begin{tabular}{|l|l|c|}
\hline $\begin{array}{l}\text { Hasil diagnosis pakar } \\
\mathbf{2}\end{array}$ & $\begin{array}{l}\text { Hasil diagnosis sistem } \\
\text { berdasarkan bobot pakar }\end{array}$ & Keterangan \\
\hline Mastitis & Mastitis (100\%) & Valid \\
\hline Brucellosis & Brucellosis (100\%) & Valid \\
\hline Bisul (Lumpy Jaw) & Bisul (Lumpy Jaw) (85\%) & Valid \\
\hline $\begin{array}{l}\text { Penyakit Kuku (Foot } \\
\text { Root) }\end{array}$ & $\begin{array}{l}\text { Penyakit Kuku (Foot Root) } \\
(100 \%)\end{array}$ & Valid \\
\hline Antraks & Antraks (98\%) & Valid \\
\hline Pneumonia & Pneumonia (100\%) & Valid \\
\hline Orf & Orf (100\%) & Valid \\
\hline $\begin{array}{l}\text { Pink Eye (Radang } \\
\text { Selaput Mata) }\end{array}$ & $\begin{array}{l}\text { Pink Eye (Radang Selaput } \\
\text { Mata) (100\%) }\end{array}$ & Valid \\
\hline $\begin{array}{l}\text { Scabies (Gudigan/ } \\
\text { Gatal) }\end{array}$ & $\begin{array}{l}\text { Scabies (Gudigan/ Gatal) } \\
(100 \%)\end{array}$ & Valid \\
\hline Kutu & Kutu (100\%) & Valid \\
\hline Kembung & Kembung (100\%) & Valid \\
\hline Diare & Diare (100\%) & Valid \\
\hline Keracunan & Keracunan (100\%) & Valid \\
\hline Kencing Batu & Kencing Batu (100\%) & Valid \\
\hline Mastitis & Mastitis (100\%) & Valid \\
\hline Kembung & $\begin{array}{l}\text { Scabies (Gudigan/ Gatal) } \\
(75 \%)\end{array}$ & Tidak Valid \\
\hline Bisul (Lumpy Jaw) & Bisul (Lumpy Jaw) (79\%) & Valid \\
\hline $\begin{array}{l}\text { Penyakit Kuku (Foot } \\
\text { Root) }\end{array}$ & $\begin{array}{l}\text { Penyakit Kuku (Foot Root) } \\
(100 \%)\end{array}$ & Valid \\
\hline Keracunan & Antraks (95\%) & Tidak Valid \\
\hline Pneumonia & Pneumonia 100\% & Valid \\
\hline Bisul & $\begin{array}{l}\text { Penyakit Kuku (Foot Root) } \\
\text { (64\%) }\end{array}$ & Tidak Valid \\
\hline $\begin{array}{l}\text { Pink Eye (Radang } \\
\text { Selaput Mata) }\end{array}$ & $\begin{array}{l}\text { Pink Eye (Radang Selaput } \\
\text { Mata) (100\%) }\end{array}$ & $\begin{array}{l}\text { Vabalid } \\
(80 \%)\end{array}$ \\
\hline Kutu & Tidadigan/ Gatal) Valid \\
\hline
\end{tabular}


TABEL VIII. LANJutan Hasil PengujIan dengan Bobot

PAKAR 2

\begin{tabular}{|l|l|c|}
\hline $\begin{array}{c}\text { Hasil diagnosis pakar } \\
\mathbf{2}\end{array}$ & $\begin{array}{l}\text { Hasil diagnosis sistem } \\
\text { berdasarkan bobot pakar } \\
\mathbf{2}\end{array}$ & Keterangan \\
\hline $\begin{array}{l}\text { Scabies (Gudigan/ } \\
\text { Gatal) }\end{array}$ & $\begin{array}{l}\text { Scabies (Gudigan/ Gatal) } \\
(89 \%)\end{array}$ & Valid \\
\hline Kembung & Kembung (100\%) & Valid \\
\hline Diare & Diare (100\%) & Valid \\
\hline Keracunan & Keracunan (97\%) & Valid \\
\hline Kencing Batu & Kencing Batu (100\%) & Valid \\
\hline Diare & Diare (100\%) & Valid \\
\hline Bisul & Kutu (64\%) & Tidak Valid \\
\hline
\end{tabular}

Berdasarkan hasil pengujian akurasi pada Tabel VII dan Tabel VIII terdapat 30 contoh kasus yang dibandingkan dengan hasil diagnosis pakar 2, terdapat 25 kasus yang sesuai (valid). Sehingga diperoleh akurasi sebesar $\frac{25}{30} x 100 \%=83.33 \%$.

TABEL IX. Hasil Pengujian dengan Bobot Pakar 3

\begin{tabular}{|c|c|c|}
\hline $\begin{array}{c}\text { Hasil diagnosis pakar } \\
3\end{array}$ & $\begin{array}{c}\text { Hasil diagnosis sistem } \\
\text { berdasarkan bobot pakar } \\
\mathbf{3}\end{array}$ & Keterangan \\
\hline Mastitis & Mastitis (100\%) & Valid \\
\hline Brucellosis & Brucellosis (100\%) & Valid \\
\hline Bisul (Lumpy Jaw) & Bisul (Lumpy Jaw) (94\%) & Valid \\
\hline $\begin{array}{l}\text { Penyakit Kuku (Foot } \\
\text { Root) }\end{array}$ & $\begin{array}{l}\text { Penyakit Kuku (Foot Root) } \\
(100 \%)\end{array}$ & Valid \\
\hline Antraks & Antraks (100\%) & Valid \\
\hline Pneumonia & Pneumonia (100\%) & Valid \\
\hline Orf & $\operatorname{Orf}(100 \%)$ & Valid \\
\hline $\begin{array}{l}\text { Pink Eye (Radang } \\
\text { Selaput Mata) }\end{array}$ & $\begin{array}{l}\text { Pink Eye (Radang Selaput } \\
\text { Mata) }(100 \%)\end{array}$ & Valid \\
\hline $\begin{array}{l}\text { Scabies (Gudigan/ } \\
\text { Gatal) }\end{array}$ & $\begin{array}{l}\text { Scabies (Gudigan/ Gatal) } \\
(100 \%)\end{array}$ & Valid \\
\hline Kutu & Kutu (95\%) & Valid \\
\hline Kembung & Kembung (100\%) & Valid \\
\hline Diare & Diare (100\%) & Valid \\
\hline Keracunan & Keracunan $(100 \%)$ & Valid \\
\hline Kencing Batu & Kencing Batu (100\%) & Valid \\
\hline Mastitis & Mastitis (100\%) & Valid \\
\hline Kembung & $\begin{array}{l}\text { Scabies (Gudigan/ Gatal) } \\
(64 \%)\end{array}$ & Tidak Valid \\
\hline Bisul (Lumpy Jaw) & Bisul (Lumpy Jaw) (85\%) & Valid \\
\hline $\begin{array}{l}\text { Penyakit Kuku (Foot } \\
\text { Root) }\end{array}$ & $\begin{array}{l}\text { Penyakit Kuku (Foot Root) } \\
(100 \%)\end{array}$ & Valid \\
\hline Antraks & Antraks (100\%) & Valid \\
\hline Pneumonia & Pneumonia (100\%) & Valid \\
\hline Orf & $\operatorname{Orf}(85 \%)$ & Valid \\
\hline $\begin{array}{l}\text { Pink Eye (Radang } \\
\text { Selaput Mata) }\end{array}$ & $\begin{array}{l}\text { Pink Eye (Radang Selaput } \\
\text { Mata) }(100 \%)\end{array}$ & Valid \\
\hline Kutu & $\begin{array}{l}\text { Scabies (Gudigan/ Gatal) } \\
(80 \%)\end{array}$ & Tidak Valid \\
\hline Mastitis & $\begin{array}{l}\text { Scabies (Gudigan/ Gatal) } \\
(87 \%)\end{array}$ & Tidak Valid \\
\hline Kembung & Kembung (100\%) & Valid \\
\hline Diare & Diare (100\%) & Valid \\
\hline Keracunan & Keracunan (97\%) & Valid \\
\hline Kencing Batu & Kencing Batu (100\%) & Valid \\
\hline Diare & Diare (100\%) & Valid \\
\hline Mastitis & $\begin{array}{l}\text { Scabies (Gudigan/ Gatal) } \\
(60 \%)\end{array}$ & Tidak Valid \\
\hline
\end{tabular}

Berdasarkan hasil pengujian akurasi pada Tabel IX terdapat 30 contoh kasus yang dibandingkan dengan hasil diagnosis pakar 3, terdapat 26 kasus yang sesuai (valid). Sehingga diperoleh akurasi sebesar $\frac{26}{30} x 100 \%=86.66 \%$.

Berdasarkan dua pengujian akurasi yang dilakukan, diperoleh nilai akurasi berdasarkan bobot rata-rata pakar sebesar $85.55 \%$. Sedangkan untuk pengujian akurasi berdasarkan bobot masig-masing pakar yaitu sebesar 86.66\%, 83.33\% dan 86.66\%. Adapun hasil akurasi pengujian menggunakan bobot masing-masing pakar dan bobot rata-rata pakar menunjukkan hasil akurasi yang sama dimana hal ini menyatakan bahwa nilai CF setiap pakar memiliki tendensi yang sama dengan nilai CF rata-rata yang menyatakan suatu informasi yang valid.

Adanya kasus yang tidak valid antara hasil diagnosis sistem dengan hasil diagnosis pakar dipengaruhi oleh nilai bobot CF yang berbeda serta pengalaman dari setiap pakar.

Berdasarkan hasil pengujian akurasi yang telah dilakukan dapat dikatakan bahwa penerapan metode Forward Chaining sebagai mesin inferensi dan Certainty Factor untuk mengambil kesimpulan berdasarkan pengetahun 3 orang pakar pada sistem telah berhasil diimplementasikan.

\section{A.4. Pengujian MOS (Mean Opinion Score)}

Pengujian MOS merupakan metode pengujian yang digunakan untuk menguji kelayakan sistem pakar diagnosis penyakit pada kambing yang telah dibangun berdasarkan pada kemudahan penggunaan sistem, tampilan sistem, kemampuan sistem dalam memberikan informasi penyakit pada kambing kemampuan sistem untuk memudahkan pengguna melakukan diagnosis penyakit pada kambing dan penggunaan sistem di masa akan datang untuk membantu diagnosis penyakit pada kambing. Penilaian mengenai sistem pakar diagnosis penyakit pada kambing diberikan oleh responden melalui kuesioner. Responden dalam pengujian ini berjumlah 30 yang terdiri dari 10 mahasiswa Program Studi Teknik Informatika, 5 mahasiswa peternakan, 5 tenaga medis (orang yang paham mengenai penyakit pada kambing) dan 10 masyarakat umum (masyarakat dan peternak kambing). Adapun hasil penilaian dihitung dengan parameter MOS untuk mendapatkan kesimpulan hasil pengujian. 
tabel $X$. Pengujian mOS Responden Mahasiswa TI

\begin{tabular}{|c|c|c|c|c|c|c|c|c|}
\hline $\begin{array}{l}\mathbf{N} \\
\mathbf{0}\end{array}$ & Pertanyaan & $\begin{array}{l}\text { SS } \\
\text { (5) }\end{array}$ & $\begin{array}{c}S \\
\text { (4) }\end{array}$ & $\begin{array}{l}\text { TT } \\
\text { (3) }\end{array}$ & $\begin{array}{l}\text { TS } \\
\text { (2) }\end{array}$ & $\begin{array}{c}\text { ST } \\
\text { S } \\
\text { (1) }\end{array}$ & $\begin{array}{c}\text { Tota } \\
\text { I }\end{array}$ & $\begin{array}{c}\text { Mean } \\
\text { pi }\end{array}$ \\
\hline 1 & Pertanyaan 1 & 3 & 7 & - & - & - & 10 & 4.30 \\
\hline 2 & Pertanyaan 2 & 1 & 8 & 1 & - & - & 10 & 4.00 \\
\hline 3 & Pertanyaan 3 & - & 9 & 1 & - & - & 10 & 3.90 \\
\hline 4 & Pertanyaan 4 & 3 & 7 & - & - & - & 10 & 4.30 \\
\hline 5 & Pertanyaan 5 & 4 & 6 & - & - & - & 10 & 4.40 \\
\hline \multirow{2}{*}{\multicolumn{8}{|c|}{\begin{tabular}{c|c|c|c|c}
37 & 2 & - & - & 50 \\
\end{tabular}}} & 20.9 \\
\hline & & & & & & & & 4.18 \\
\hline
\end{tabular}

\section{Keterangan:}

Pertanyaan 1: $\quad$ Tampilan sistem pakar diagnosis penyakit pada kambing ini menarik dan mudah digunakan (user friendly)

Pertanyaan 2: $\quad$ Penggunaan warna tampilan dan jenis huruf pada sistem pakar ini sudah sesuai

Pertanyaan 3: Menu yang ditampilkan pada sistem sudah cukup dan sesuai (tidak diperlukan menu pengurangan atau penambahan lagi)

Pertanyaan 4: $\quad$ Informasi yang ditampilkan sesuai dengan tujuan pembangunan sistem

Pertanyaan 5: $\quad$ Sistem pakar diagnosis penyakit pada kambing ini layak digunakan

Berdasarkan hasil pengujian MOS pada Tabel X yang diperoleh dari hasil kuesioner 10 responden mahasiswa TI yang memiliki pemahaman tentang sistem, didapatkan kesimpulan hasil perhitungan MOS sebesar 4.18 dari skala 5. Berdasarkan nilai tersebut menandakan bahwa dari segi kualitas sistem (baik dari segi interface maupun teknis sistem) yang dibangun sudah baik.

tabel XI. Pengujian MOS Responden Mahasiswa PETERNAKAN

\begin{tabular}{|c|c|c|c|c|c|c|c|c|}
\hline No & Pertanyaan & $\begin{array}{l}\text { SS } \\
\text { (5) }\end{array}$ & $\begin{array}{c}S \\
(4)\end{array}$ & $\begin{array}{l}\text { TT } \\
\text { (3) }\end{array}$ & $\begin{array}{l}\text { TS } \\
\text { (2) }\end{array}$ & $\begin{array}{c}\text { ST } \\
\text { S } \\
\text { (1) }\end{array}$ & $\begin{array}{c}\text { Tota } \\
\text { I }\end{array}$ & $\begin{array}{c}\text { Mean } \\
\quad \text { pi }\end{array}$ \\
\hline 1 & Pertanyaan 1 & 1 & 4 & - & - & - & 5 & 4.20 \\
\hline 2 & Pertanyaan 2 & 1 & 4 & - & - & - & 5 & 4.20 \\
\hline 3 & Pertanyaan 3 & 2 & 3 & - & - & - & 5 & 4.40 \\
\hline 4 & Pertanyaan 4 & 2 & 3 & - & - & - & 5 & 4.40 \\
\hline 5 & Pertanyaan 5 & 4 & 1 & - & - & - & 5 & 4.80 \\
\hline & Sub Total & 10 & 15 & - & - & - & 25 & 22 \\
\hline \multicolumn{8}{|c|}{ MOS (Mean Opinion Score) } & 4.40 \\
\hline
\end{tabular}

Keterangan:

Pertanyaan 1: Tampilan sistem pakar diagnosis penyakit pada kambing ini menarik dan mudah digunakan (user friendly)

Pertanyaan 2: Informasi penyakit dan gejala yang ditampilkan sudah
Pertanyaan 3: Pemilihan gambar pendukung sesuai dengan informasi yang ditampilkan

Pertanyaan 4: $\quad$ Sistem pakar ini dapat memberikan informasi saran pencegahan penyakit pada kambing

Pertanyaan 5: $\quad$ Sitem pakar ini dapat membantu melakukan diagnosis penyakit pada kambing menjadi lebih mudah dan layak digunakan

Berdasarkan hasil pengujian MOS pada Tabel XI yang diperoleh dari hasil kuesioner 5 responden mahasiswa peternakan yang memiliki pemahaman tentang penyakit pada kambing dan sebagai pengguna android, didapatkan kesimpulan hasil perhitungan MOS sebesar 4.40 dari skala 5. Berdasarkan nilai tersebut menandakan bahwa dari segi kualitas sistem (baik dari segi informasi penyakit maupun gambar pendukung) yang dibangun sudah baik.

TABEL XII. PEnguJIAN MOS RESPONDEN TENAGA MEDIS

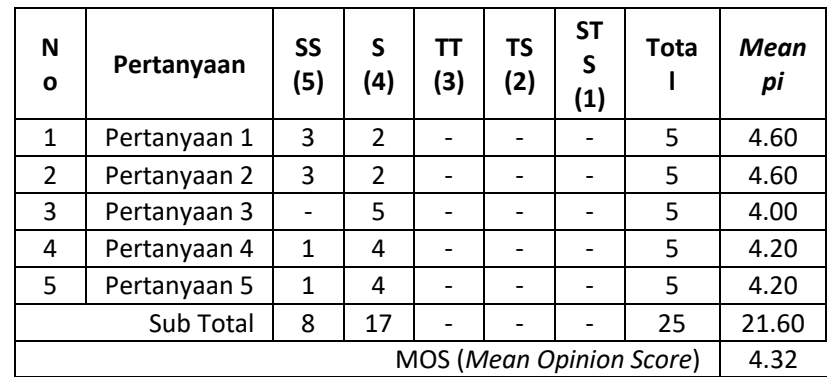

\section{Keterangan:}

Pertanyaan 1: Tampilan sistem pakar diagnosis penyakit pada kambing ini menarik dan mudah digunakan (user friendly)

Pertanyaan 2: Adanya sistem pakar ini dapat membantu untuk mendiagnosis penyakit pada kambing menjadi lebih mudah

Pertanyaan 3: Informasi saran pencegahan yang ditampilkan sudah sesuai dan layak untuk diterapkan

Pertanyaan 4: Informasi gejala, penyakit serta hasil diagnosis yang ditampilkan sudah relevan dengan kasus yang pernah ditangani

Pertanyaan 5: Sistem pakar diagnosis penyakit pada kambing ini layak digunakan berdasarkan keakuratan informasi yang disajikan

Berdasarkan hasil pengujian MOS pada Tabel XII yang diperoleh dari hasil kuesioner 5 responden tenaga medis atau orang yang paham mengenai kambing yang memiliki pemahaman tentang penyakit pada kambing 
dan sebagai pengguna android, didapatkan kesimpulan hasil perhitungan MOS sebesar 4.32 dari skala 5 . Berdasarkan nilai tersebut menandakan bahwa dari segi kualitas sistem (baik dari segi keakuratan informasi penyakit, kesesuaian hasil diagnosis maupun kelayakan sistem) yang dibangun sudah baik.

tabel XIII. Pengujian mos Responden Masyarakat Umum

\begin{tabular}{|c|c|c|c|c|c|c|c|c|}
\hline $\begin{array}{l}\mathbf{N} \\
0\end{array}$ & Pertanyaan & $\begin{array}{l}\text { SS } \\
\text { (5) }\end{array}$ & $\begin{array}{c}S \\
\text { (4) }\end{array}$ & $\begin{array}{l}T T \\
\text { (3) }\end{array}$ & $\begin{array}{l}\text { TS } \\
\text { (2) }\end{array}$ & $\begin{array}{c}\text { ST } \\
\text { S } \\
(1)\end{array}$ & $\begin{array}{c}\text { Tota } \\
\text { I }\end{array}$ & $\begin{array}{c}\text { Mean } \\
p i\end{array}$ \\
\hline 1 & Pertanyaan 1 & 9 & 1 & - & - & - & 10 & 4.90 \\
\hline 2 & Pertanyaan 2 & 4 & 6 & - & - & - & 10 & 4.40 \\
\hline 3 & Pertanyaan 3 & 3 & 7 & - & - & - & 10 & 4.30 \\
\hline 4 & Pertanyaan 4 & 7 & 3 & - & - & - & 10 & 4.70 \\
\hline 5 & Pertanyaan 5 & 3 & 7 & - & - & - & 10 & 4.30 \\
\hline \multirow{2}{*}{\multicolumn{8}{|c|}{ Score) }} & 22.60 \\
\hline & & & & & & & & 4.52 \\
\hline
\end{tabular}

Keterangan:

Pertanyaan 1: Tampilan sistem pakar diagnosis penyakit pada kambing ini menarik dan mudah digunakan (user friendly)

Pertanyaan 2: Informasi gejala dan penyakit (penggunaan istilah) yang ditampilkan mudah dimengerti

Pertanyaan 3: $\quad$ Sistem pakar ini dapat memberikan informasi saran pencegahan penyakit pada kambing

Pertanyaan 4: $\quad$ Sitem pakar ini dapat menambah pengetahuan masyarakat serta membantu masyarakat melakukan diagnosis penyakit pada kambing menjadi lebih mudah

Pertanyaan 5: Pada waktu mendatang anda akan menggunakan sistem ini untuk melakukan konsultasi penyakit pada kambing apabila sewaktu-waktu gejala terdapat pada kambing

Berdasarkan hasil pengujian MOS pada Tabel XIII yang diperoleh dari hasil kuesioner 10 responden masyarakat umum atau peternak kambing sebagai pengguna android, didapatkan kesimpulan hasil perhitungan MOS sebesar 4.52 dari skala 5 . Berdasarkan nilai tersebut menandakan bahwa dari segi kualitas sistem (baik dari segi kemudahan penggunaan sistem maupun istilah-istilah yang digunakan) yang dibangun sudah baik.

Berdasarkan hasil pengujian MOS pada Tabel X, Tabel XI, Tabel XII, dan Tabel XIII yang diperoleh dari hasil kuesioner 30 responden, didapatkan kesimpulan hasil rata-rata perhitungan MOS sebesar 4.35 dari skala 5, dimana dapat hal ini menunjukkan bahwa kualitas sistem pakar diagnosis penyakit pada kambing dengan metode Forward Chaining dan Certainty Factor yang dibangun sudah baik. Pernyataan hasil kualitas sistem ini berdasarkan pada tabel skala opinion dan bobot dimana pada tabel tersebut diketahui bahwa sistem dengan rentang nilai MOS 4 sampai dengan 5 dikelompokkan ke dalam kategori baik (good).

\section{KESIMPULAN DAN SARAN}

Berdasarkan hasil penelitian dan pengujian yang telah dilakukan didapatkan hasil pengujian akurasi sistem pakar diagnosis penyakit pada kambing dengan metode Forward Chaining dan Certainty Factor dengan 30 contoh kasus yang diujikan kepada 3 orang pakar, diperoleh nilai akurasi berdasarkan bobot rata-rata 3 orang pakar sebesar $85.55 \%$, berdasarkan bobot masing-masing pakar sebesar $86.66 \%, 83.33 \%$, dan $86.66 \%$, dimana adanya kasus yang tidak valid antara hasil diagnosis sistem dengan hasil diagnosis pakar dipengaruhi oleh bobot CF yang berbeda serta pengalaman dari setiap pakar. Berdasarkan nilai akurasi yang diperoleh tersebut menunjukkan bahwa performa metode Forward Chaining dan Certainty Factor dalam mendiagnosis penyakit pada kambing sudah baik dan dapat diterapkan pada kasus penyakit kambing.

Berdasarkan hasil pengujian MOS (Mean Opinion Score) yang telah dilakukan, didapatkan nilai MOS sebesar 4.35 dari skala 5, dengan demikian sistem pakar yang dibangun sudah layak untuk digunakan dan dikategorikan kedalam sistem yang baik (good).

Sistem pakar diagnosis penyakit pada kambing diharapkan dapat dikembangkan dengan menggunakan metode lain seperti Dempster Shafer dan Naïve Bayes sehingga dapat dilihat perbandingan setiap metode untuk mengetahui metode yang lebih baik dalam mendiagnosis penyakit pada kambing. Selain itu juga perlu dilakukan penelitian yang membandingkan penggunaan metode Forward Chaining dan penelitian yang tidak menggunakan metode Forward Chaining sebagai mesin inferensi guna mengetahui performa yang terbaik.

\section{UCAPAN TERIMA KASIH}

Terima kasih penulis ucapkan kepada para pakar drh. Made Sriasih, M. Agr, Sc., Ph.D., drh. Kholik, M.Vet., drh. Novarina S.I.N., M.Si. yang telah bersedia memberikan data dan melakukan pengujian, serta teman-teman yang telah membantu dan berkontribusi dalam diskusi dan pembuatan program pada penelitian ini.

\section{DAFTAR PUSTAKa}

[1] I. Apriliya and I. Wahyuni, "Sistem Diagnosis Penyakit pada Kambing Menggunakan Metode Forward Chaining," J. IIm. Teknol. Inf. Asia, vol. 11, no. 2, p. 113, 2017. 
[2] Badan Pusat Statistik, "Populasi Kambing menurut Provinsi, 2009-2018," Badan Pusat Statistik, 2019. [Online]. Available: https://www.bps.go.id/linkTableDinamis/view/id/1 022. [Accessed: 28-Sep-2019].

[3] Direktorat Jenderal Peternakan dan Kesehatan Hewan Kementerian Pertanian RI, Statistik Peternakan dan Kesehatan Hewan 2018/ Livestock and Animal Health Statistics 2018. 2018.

[4] M. Orisa, P. B. Santoso, and O. Setyawati, "Sistem Pakar Diagnosis Penyakit Kambing Berbasis Web Menggunakan Metode Certainty Factor," J. EECCIS, vol. 8, no. 2, pp. 151-156, 2014.

[5] M. E. Bimantari, "Sistem Pakar Diagnosa Penyakit Kambing Dan Domba Menggunakan Metode Certainty Factor (Studi Kasus Unit Pelaksana Teknis Pembibitan Ternak (UPT) Dan Hijau Makanan Ternak (HMT) Garahan)," 2017.

[6] H. Brilian Argario, N. Hidayat, and R. Kartika Dewi, "Implementasi Metode Naive Bayes Untuk Diagnosis Penyakit Kambing ( Studi Kasus : UPTD . Pembibitan Ternak dan Hijauan Makanan Ternak Kec. Singosari Malang)," J. Pengemb. Teknol. Inf. dan IImu Komput., vol. 2, no. 8, pp. 2719-2723, 2018.

[7] R. R. Fanny, N. A. Hasibuan, and E. Buulolo, "Perancangan Sistem Pakar Diagnosa Penyakit Asidosis Tubulus Renalis Menggunakan Metode Certainty Factor Dengan Penulusuran Forward Chaining," Media Inform. Budidarma, vol. 1, no. 1, pp. 13-16, 2017.

[8] A. Ardiansyah and L. Muflikhah, Suprapto, "Sistem Pakar Diagnosis Penyakit Pada Kambing Menggunakan Metode Dempster Shafer," J. Pengemb. Teknol. Inf. dan IImu Komput., vol. 2, no. 8, pp. 2587-2594, 2018.

[9] M. A. Ramzy, R. N. Sarbini, and D. E. Yuliana, “Pengembangan Sistem Pakar Diagnosa Penyakit Kambing Menggunakan Metode Forward Chaining Berbasis Android," J. IIm. Setrum, vol. 7, no. 2, pp. 269-277, 2018.

[10] P. P. Abdullah, Sistem Pakar Untuk Mendiagnosa Penyakit Pada Ayam Dengan Metode Certainty Factor Berbasis Android, no. June. 2016.

[11] S. Halim and S. Hansun, "Penerapan Metode Certainty Factor dalam Sistem Pakar Pendeteksi Resiko Osteoporosis dan Osteoarthritis," J. Ultim. Comput., vol. 7, no. 2, pp. 59-69, 2015.

[12] D. T. Yuwono, A. Fadlil, and S. Sunardi, "Penerapan Metode Forward Chaining Dan Certainty Factor Pada Sistem Pakar Diagnosa Hama Anggrek Coelogyne Pandurata," Kumpul. J. Ilmu Komput., vol. 4, no. 2, p. 136, 2017.

[13] A. S. Hafshah and D. M. Khairina, "Pendeteksi Gangguan Jaringan Lokal Menggunakan Metode Certainty Factor," Inform. Mulawarman J. IIm. IImu
Komput., vol. 13, no. 2, p. 60, 2019.

[14] P. S. Ramadhan and U. F. S. Pane, "Analisis Perbandingan Metode ( Certainty Factor , Dempster Shafer dan Teorema Bayes ) untuk Mendiagnosa Penyakit Inflamasi Dermatitis Imun pada Anak," Sains dan Komput., vol. 17, no. 2, pp. 151-157, 2018.

[15] I. Candra Dewi, A. Andy Soebroto, and M. Tanzil Furqon, "Sistem Pakar Diagnosa Penyakit Sapi Potong Dengan Metode Naive Bayes," J. Enviromental Eng. Sustain. Technol., vol. 2, no. 2, pp. 72-78, 2015.

[16] R. M. Candra and W. Rahim, "Sistem Pakar Diagnosa Bibit Unggul Sapi dan Kambing Dengan Metode Certainty Factor," J. IIm. Komput. dan Inform. (KOMPUTA ), vol. 3, no. 1, 2014.

[17] R. Ramadhan, I. F. Astuti, and D. Cahyadi, "Sistem Pakar Diagnosis Penyakit Kulit Pada Kucing Persia Menggunakan Metode Certainty Factor," Pros. Semin. IImu Komput. dan Teknol. Inf., vol. 2, no. 1, pp. 263-269, 2017.

[18] A. Affan, S. Nugraha, N. Hidayat, and L. Fanani, "Sistem Pakar Diagnosis Penyakit Kucing Menggunakan Metode Naive Bayes - Certainty Factor Berbasis Android," J. Pengemb. Teknol. Inf. dan Ilmu Komput. Univ. Brawijaya, vol. 2, no. 2, pp. 650-658, 2018.

[19] Y. Permana, I. G. P. S. Wijaya, and F. Bimantoro, "Sistem Pakar Diagnosa Penyakit Mata Menggunakan Metode Certainty Factor Berbasis Android," J. Comput. Sci. Informatics Eng., vol. 1, no. 1, p. 1, 2018.

[20] S. Dodit and A. Rini, "Pemrograman Aplikasi Android," Malang, 2018.

[21] A. Rosana Mz, "Sistem Pakar Diagnosa Penyakit Kulit Pada Manusia Dengan Metode Dempster Shafer," 2019.

\section{Lampiran 1. Nilai Rata- Rata CF Pakar}

Kuesioner Pengisisan Bobot (Nilai CF) Penvakit oleh Pakar

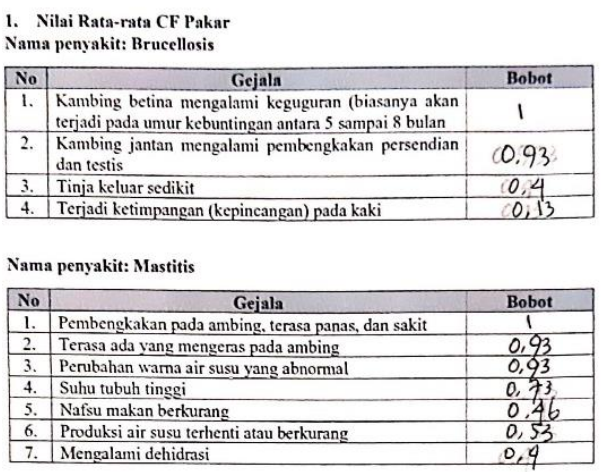


Nama penyakit: Bisul (Lumpy Jaw)

\begin{tabular}{|c|l|c|}
\hline$N_{0}$ & \multicolumn{1}{|c|}{ Gejala } & Bobot \\
\hline 1. & Pembengkakan pada kelenjar getah bening & 0,73 \\
\hline 2. & Pembengkakan pada kelenjar $3-5 \mathrm{~cm}$ & 0,66 \\
\hline 3. & Terasa panas & 0,6 \\
\hline
\end{tabular}

Nama penyakit: Penyakit Kuku (Foot Rot)

\begin{tabular}{|c|l|c|}
\hline No & \multicolumn{1}{|c|}{ Gejala } & Bobot \\
\hline 1. & Terjadi ketimpangan (kepincangan) pada kaki & 1 \\
\hline 2. & Cenderung berdiam diri & 0,73 \\
\hline 3. & Nafsu makan berkurang & 0,53 \\
\hline 4. & Ternak terlihat kurus & 0,53 \\
\hline 5. & Pembengkakan pada kuku & 0,93 \\
\hline 6. & Keluar nanah pada luka & 0,93 \\
\hline 7. & Kulit sekitar kaki melepuh & 1 \\
\hline
\end{tabular}

Nama penyakit: Antraks

\begin{tabular}{|c|l|c|}
\hline No & \multicolumn{1}{|c|}{ Gejala } & Bobot \\
\hline 1. & Suluo tubuh tinggi & 0,8 \\
\hline 2. & Kematian mendadak & 0,93 \\
\hline 3. & Terlihat stress & 0,6 \\
\hline 4. & Selaput lendir dan mata berwarna merah tua & 0,86 \\
\hline 5. & Diare berdarah & 0,86 \\
\hline 6. & Denyut nadi cepat dan lemah & 0,86 \\
\hline 7. & Nafsu makan berkurang & 0,6 \\
\hline 8. & Urin berwama merah & 0,86 \\
\hline 9. & Pembengkakan pada lidah dan kerongkongan & 0,73 \\
\hline 10. & Perubahan wama air susu yang abnormal & 0,66 \\
\hline
\end{tabular}

Nama penyakit: Pneumonia

\begin{tabular}{|c|l|c|}
\hline No & \multicolumn{1}{|c|}{ Gejala } & Bobot \\
\hline 1. & Mengcluarkan ingus & 0,8 \\
\hline 2. & Lidah keluar & 0,66 \\
\hline 3. & Suhu tubuh tinggi & 0,6 \\
\hline 4. & Nafsu makan berkurang & 0,6 \\
\hline 5. & Ternak terlihat lemah & 0,6 \\
\hline 6. & Ternak mengalami batuk & 0,73 \\
\hline 7. & Sulit bernafas & 1 \\
\hline
\end{tabular}

Nama penyakit: $O r f$

\begin{tabular}{|c|l|c|}
\hline No & \multicolumn{1}{|c|}{ Gejala } & Bobot \\
\hline 1. & $\begin{array}{l}\text { Timbulnya lesi di sekitar wajah, kaki, ambing dan } \\
\text { skrotum }\end{array}$ & 1 \\
\hline 2. & Ternak terlihat lesu & 0,66 \\
\hline 3. & Sulit bernafas & 0,66 \\
\hline 4. & Lidah keluar & 0,53 \\
\hline 5. & Mulut berbau asam & 0,46 \\
\hline 6. & Mulut mengeluarkan cairan & 0,4 \\
\hline 7. & Nafsu makan berkurang & 0,66 \\
\hline 8. & Pembengkakan pada mulut & 0,86 \\
\hline
\end{tabular}

Nama penyakit: Pink Eye (Radang Selaput Mata)

\begin{tabular}{|c|l|c|}
\hline No & \multicolumn{1}{|c|}{ Gejala } & Bobot \\
\hline 1. & Mata berair & 0,93 \\
\hline 2. & Kemerahan pada bagian putih mata & 1 \\
\hline 3. & Kelopak mata membengkak & 0,86 \\
\hline 4. & Kornea mata menjadi keruh atau tertutup lapisan putih & 0,86 \\
\hline
\end{tabular}

Nama penyakit: Scabies (Gudigan/Gatal)

\begin{tabular}{|c|l|c|}
\hline No & \multicolumn{1}{|c|}{ Gejala } & Bobot \\
\hline 1. & Gatal pada kulit & 1 \\
\hline 2. & Pencbalan pada bagian kulit yang gatal & 1 \\
\hline 3. & Nafsu makan berkurang & 0,73 \\
\hline 4. & Ternak terlihat kurus & 0,73 \\
\hline 5. & Bulu terlihat kusam & 0,6 \\
\hline 6. & Produktivitas merurun & 0,66 \\
\hline 7. & Terdapat gumpalan pada tubuh & 0,53 \\
\hline 8. & Bulu rontok & 0,86 \\
\hline
\end{tabular}

Nama penyakit: Kutu

\begin{tabular}{|c|l|l|}
\hline No & \multicolumn{1}{|c|}{ Gejala } & Bobot \\
\hline 1. & Terlihat pucat (anemia) & 0,8 \\
\hline 2. & Bulu rontok & 0,93 \\
\hline 3. & Ternak terlihat kurus & 0,6 \\
\hline 4. & Ternak terlihat lemah & 0,66 \\
\hline 5. & Produksi susu menurum & 0,53 \\
\hline 6. & Pertumbuhan ternak menurun & 0,6 \\
\hline
\end{tabular}

Nama penyakit: Kembung

\begin{tabular}{|c|l|c|}
\hline No & \multicolumn{1}{|c|}{ Gejala } & Bobot \\
\hline 1. & Terlihat tidak tenang (gelisah) & 0,8 \\
\hline 2. & Sulit bernafas & 0,8 \\
\hline 3. & Sisi tubuh bagian kiri membesar & 1 \\
\hline 4. & Apabila di tepuk terdengar suara seperti drum & 1 \\
\hline 5. & $\begin{array}{l}\text { Gerakan rumen berlangsung terus sampai bagian dalam } \\
\text { mulut }\end{array}$ & 0,86 \\
\hline 6. & Daerah mata terlihat membiru & 0,86 \\
\hline 7. & Ternak terlihat lemah & 0,73 \\
\hline 8. & Nafsu makan menurun & 0,66 \\
\hline 9. & Sulit berdiri atau ambruk & 0,8 \\
\hline
\end{tabular}

Nama penyakit: Diare

\begin{tabular}{|c|l|c|}
\hline No & \multicolumn{1}{|c|}{ Gejala } & Bobot \\
\hline 1. & Ternak terlihat lemah & 0,86 \\
\hline 2. & Feses akan berubah warna dan konsistensi & 0,93 \\
\hline 3. & Suhu tubuh tinggi & 0,66 \\
\hline 4. & Feses cair dan berbau busuk & 1 \\
\hline 5. & Nafsu makan berkurang & 0,8 \\
\hline
\end{tabular}

Nama penyakit: Keracunan

\begin{tabular}{|c|l|c|}
\hline No & \multicolumn{1}{|c|}{ Gejala } & Bobot \\
\hline 1. & Mulut mengeluarkan busa & 1 \\
\hline 2. & Feses berdarah & 0,66 \\
\hline 3. & Muka membengkak & 0,6 \\
\hline 4. & Kejang otot & 0,86 \\
\hline 5. & Kelenjar mukosa membiru & 0,93 \\
\hline 6. & Pernafasan menjadi cepat & 0,93 \\
\hline 7. & Sulit berdiri atau ambruk & 0,86 \\
\hline 8. & Kejang-kejang & 0.93 \\
\hline
\end{tabular}

\section{Nama penyakit: Kencing Batu}

\begin{tabular}{|c|l|c|}
\hline No & \multicolumn{1}{|c|}{ Gejala } & Bobot \\
\hline 1. & Sulit mengeluarkan urin & 1 \\
\hline 2. & Ternak menggaruk perut & 0,73 \\
\hline 3. & $\begin{array}{l}\text { Ternak terlihat berbaring dan meragang mencoba untuk } \\
\text { mengeluarkan urin }\end{array}$ & 1 \\
\hline
\end{tabular}

